\title{
FAKTOR-FAKTOR YANG MEMPENGARUHI RENDAHNYA PENGGUNAKAN ALAT KONTRASEPSI IUD DI WILAYAH KERJA UPTD PUSKESMA DTP SUKARAME TAHUN 2014.
}

Oleh :

Chanty Yunie, S.ST.,M.Kes

\section{A. Abstrak}

Di Wilayah UPTD Puskesma DTP Sukarame, dari 7196 peserta KB paling banyak menggunakan suntik akseptor (44,69\%), menyusul akseptor yang mengggunakan pil $(1,22 \%)$ sedangkan jenis alat kontrasepsi yang paling sedikit dipilih adalah IUD 367 akseptor (5,10\%). Berdasarkan data tersebut pengguna alat kontrasepsi IUD adalah pengguna yang paling rendah di wilayah tersebut. Tujuan dari penelitian ini adalah mengetahui Faktor-Faktor Yang Mempengaruhi Rendahnya Penggunakan Alat Kontrasepsi IUD Di wilayah kerja UPTD Puskesma DTP Sukarame tahun 2014.

Penelitian jenis kuantitatif dengan metode deskriptif,yang bertujuan untuk mengambarkan Faktor-Faktor Yang Mempengaruhi Rendahnya Penggunakan Alat Kontrasepsi IUD Di wilayah kerja UPTD Puskesma DTP Sukarame tahun 2014.Populasi penelitian adalah seluruh pasangan usia subur sejumlah 1068 orang, dengan pengambilan sampel dalam menggunakan proportional Random Sampling. Selanjutnya dilakukan pengambilan sampel dari tiap kelurahan dengan teknik proportional random sampling. Instrumen utama dalam penelitian ini menggunakan format kusioner dengan wawancara untuk melihat penggunaan alat kontrasepsi AKDR.

Hasil penelitian menyatakan bahwa sebagian besar pada kelompok usia 20-35 tahun, Paritas responden primipara, Pendidikan responden sebagian termasuk rendah, Sebagian besar responden tidak mendapat KIE dari petugas kesehatan, Sebagian besar responden tidak mendapat dukungan serta Sebagian besar responden memiliki pendapatan kurang dari UMR .

Saran yang direkomendasikan bahwa penggunaan alat kontasepsi jangka panjang khususnya IUD petugas perlu melakukan sosialisasi sesuai dengan tujuan dan karakteristik akseptor. Disamping itu masyarakat perlu meningkatkan pengetahuan tentang alat kontrasepsi sesuai dengan peruntukannya.

Kata Kunci : Pengguna IUD, usia, paritas pendidikan, KIE, dukungan suami serta pendapata keluarga. 


\section{B. Latar belakang}

Laju pertumbuhan penduduk Indonesia saat ini sudah memasuki tahap sangat mengkhawatirkan. Jika laju pertumbuhan penduduk ini tidak segera diantisipasi, maka pada 10-15 tahun ke depan Indonesia akan mengalami ledakan penduduk tidak terkendali. Pada tahun 2007 tercatat rata-rata angka kelahiran mencapai 3 anak per wanita subur, sedangkan laju pertumbuhan penduduk rata-rata 2,6 juta jiwa per tahun. Tingginya laju pertumbuhan penduduk dan angka kelahiran di Indonesia tersebut, hal tersebut diperparah dengan pola penyebaran penduduk yang tidak merata. Apabila hal tersebut tidak segera dikendalikan, maka hal itu akan jadi beban yang berat bagi pemerintah.( BKKBN : $2010: 2$ ).

Berdasarkan hasil Survei Demografi dan Kependudukan Indonesia (SDKI) Dari $61,4 \%$ pengguna metode kontrasepsi di indonesia tahun 2008, pola pemakaian kontrasepsi terbesar yaitu suntik sebesar $31,6 \%$, pil sebesar $13,2 \%$, IUD sebesar 4,8\%, implant $2,8 \%$, kondom sebesar $1,3 \%$, kontap wanita (Medis Operasi Wanita-MOW) sebesar 3,1\% dan kontap pria (Medis Operasi Pria -MOP) sebesar 0,2\%, pantang berkala 1,5\%, senggama terputus $2,2 \%$ dan metode lainnya $0,4 \%$. (SDKI: 2008 :34).

Berdasarkan hasil pendahuluan diperoleh data adanya wanita usia subur dengan paritas tinggi, usia lebih dari 35 tahun yang belum memperoleh pelayanan kontrasepsi yang tidak sesuai atau yang seharusnya sudah menggunakan kontrasepsi metode jangka panjang. Kontrasepsi implan merupakan metodekontrasepsi yang kurang diminati oleh masyarakat, hal tersebut dapat disebabkan karena sebagian besar ibu akseptor KB kurang mendapat informasitentang kontrasepsi baik kelebihan maupun kekurangannya. (Sarwono : $2006: 8$ ).
Banyak faktor yang mempengaruhi perilaku dalam pemilihan alat kontrasepsi. Menurut Green dan Kreuter (2005) terdapat tiga kelompok faktor yang mempengaruhi perilaku seseorang, yaitu faktor-faktor predisposisi (predisposing factors), faktor-faktor pendukung (enabling factors), dan faktor-faktor pendorong (reinforcing factors). Jika dihubungkan dengan pemilihan alat kontrasepsi, maka faktor predisposisi yang berpengaruh adalah usia, pendidikan, pengetahuan, paritas, jarak persalinan, status kesehatan ibu. Faktor pendukung yang berpengaruh meliputi keterjangkauan pelayanan kesehatan, metode, sedangkan faktor pendorong terdiri dari dukungan suami, dukungan orang tua, dan dukungan petugas kesehatan.(Nottoatmodjo : 2005 :28).

Dari berbagai faktor yang mempengaruhi pemilihan alat kontrasepsi, faktor pengetahuan adalah hal yang sangat penting dalam membentuk tindakan seseorang, termasuk perilaku ibu dalam memilih alat kontrasepsi. Sebuah perilaku yang didasari oleh pengetahuan, kesadaran, dan sikap positif akan membentuk sebuah perilaku yang langgeng, sebaliknya sebuah perilaku yang tidak did asari oleh pengetahuan dan kesadaran akan membuat perilaku tersebut tidak akanbertahan lama. Kurangnya pengetahuan ataupun kurangnya kemampuan ibu dalam menerapkan informasi tentang alat kontrasepsi implan sangat berpengaruh terhadap perilaku ibu dalam pemilihan alat kontrasepsi ( Nottoatmojo :2005 :31).

Sedangkan akseptor KB di Kabupaten Tasikmalaya pada tahun 2009 sebanyak 268.836 orang dengan PUS (Pasangan Usia Subur) sebanyak 364.431 orang, terdiri dari pengguna pil sebanyak $21,4 \% \%$, suntik $40,5 \% \%$, implant 2,4\%, AKDR 6,39\%, kondom $1,5 \%$, sterilisasi 1,32\%. (Laporan 
tahunan Dinas Kesehatan Kabupaten Tasikmalaya: 2009 :19).

Di Wilayah UPTD Puskesma DTP Sukarame, dari 7196 peserta KB paling banyak menggunakan suntik akseptor (44,69\%), menyusul akseptor yang mengggunakan pil $(1,22 \%)$ sedangkan jenis alat kontrasepsi yang paling sedikit dipilih adalah IUD 367 akseptor $(5,10 \%)$.

Berdasarkan data tersebut pengguna alat kontrasepsi IUD adalah pengguna yang paling rendah di wilayah tersebut. Di wilayah UPTD Puskesma DTP Sukarame pengguna alat kontrasepsi IUD yang paling rendah adalah wilayah

\section{Metode}

Penelitian jenis kuantitatif dengan metode deskriptif,yang bertujuan untuk mengambarkan Faktor-Faktor Yang Mempengaruhi Rendahnya Penggunakan Alat Kontrasepsi IUD Di wilayah kerja UPTD Puskesma DTP Sukarame tahun 2014.
UPTD Puskesma DTP Sukarame. (Laporan KIA /KB UPTD Puskesma DTP Sukarame : 2012).

Berdasarkan data di atas penulis bermaksud untuk melakukan penelitian yang berjudul " Faktor-Faktor Yang Mempengaruhi Rendahnya Penggunakan Alat Kontrasepsi IUD Di wilayah kerja UPTD Puskesma DTP Sukarame tahun 2014.

Tujuan dari penelitian ini adalah mengetahui Faktor-Faktor Yang Mempengaruhi Rendahnya Penggunakan Alat Kontrasepsi IUD Di wilayah kerja UPTD Puskesma DTP Sukarame tahun 2014.

Populasi penelitian adalah seluruh pasangan usia subur sejumlah 1068 orang, dengan pengambilan sampel dalam menggunakan proportional Random Sampling.

Selanjutnya dilakukan pengambilan sampel dari tiap kelurahan dengan teknik proportional random sampling

Tabel 1 Sebaran Sampel dari tiap Desa di wilayah kerja Puskesmas Sukarame

\begin{tabular}{|l|c|c|c|}
\hline \multicolumn{1}{|c|}{ Desa } & Ibu Usia Subur & Total Populasi & Sampel \\
\hline Sukarame & 164 & 1068 & 61 \\
\hline Sukarapih & 187 & 1068 & 70 \\
\hline Sukamenak & 167 & 1068 & 63 \\
\hline Wargakerta & 189 & 1068 & 71 \\
\hline Padasuka & 182 & 1068 & 68 \\
\hline Sukakarsa & 179 & 1068 & 67 \\
\hline \multicolumn{3}{|c|}{ Jumlah sampel } \\
\hline
\end{tabular}

Instrumen utama dalam penelitian ini menggunakan format kusioner dengan wawancara untuk melihat penggunaan alat kontrasepsi AKDR.

Pengumpulan data dilakukan oleh peneliti dengan terlebih dahulu mempersiapkan berbagai format yang dibutuhkan sebagai instrumen guna memudahkan pengumpulan data. Pengumpulan data dalam penelitian ini adalah data primer, dimana data langsung didapatkan dari responden melalui hasil tanya dari peneliti, Pengumpulan data sekunder sebagai datapendukung dilakukan dengan cara melakukan telaah dokumen yang sesuai dengan substansi dan kebutuhan penelitian. 


\section{Hasil penelitian}

1. Hasil Penelitian

a. Usia

Tabel 2

Distribusi usia responden di Wilayah Kerja UPTD Puskesmas DTP Sukarame tahun 2013

\begin{tabular}{|l|c|c|}
\hline \multicolumn{1}{|c|}{ Usia } & F & \% \\
\hline$<20$ tahun & 117 & 29,2 \\
\hline $20-35$ tahun & 244 & 61,0 \\
\hline$>35$ tahun & 39 & 9,8 \\
\hline Jumlah & $\mathbf{4 0 0}$ & $\mathbf{1 0 0}$ \\
\hline
\end{tabular}

Data pada tabel 2 menunjukkan penyebaran responden menurut usia sebagian besar pada kelompok usia 20-35 tahun yaitu 61\%, dan pada kelompok usia $<20$ tahun sebanyak $29.3 \%$, sedangkan pada kelompok usia $>35$ tahun sebanyak $9,8 \%$.

b. Paritas

Tabel 3

Distribusi paritas responden di Wilayah Kerja UPTD Puskesmas DTP Sukarame tahun 2013

\begin{tabular}{|l|c|c|}
\hline \multicolumn{1}{|c|}{ Paritas } & f & \% \\
\hline Primipara & 257 & 64,2 \\
\hline Multipara & 115 & 28,8 \\
\hline Grandepara & 28 & 7,0 \\
\hline Jumlah & $\mathbf{4 0 0}$ & $\mathbf{1 0 0}$ \\
\hline
\end{tabular}

Data pada tabel 3 menunjukkan paritas responden sebagian besar termasuk primipara yaitu $64.3 \%$, dan paritas multipara sebanyak $28.8 \%$, sedangkan paritas grandepara sebanyak $7.0 \%$.

c. Pendidikan

Tabel 4

Distribusi usia responden di Wilayah Kerja UPTD Puskesmas DTP Sukarame tahun 2013

\begin{tabular}{|l|c|c|}
\hline \multicolumn{1}{|c|}{ Pendidikan } & f & \% \\
\hline Rendah & 213 & 53,2 \\
\hline Tinggi & 187 & 46,8 \\
\hline Jumlah & $\mathbf{4 0 0}$ & $\mathbf{1 0 0}$ \\
\hline
\end{tabular}

Data pada tabel 4 menunjukkan pendidikan responden sebagian termasuk rendah yaitu sebanyak $53.3 \%$, dan pendidikan tinggi sebanyak $46.8 \%$.

d. Komunikasi, Informasi dan Edukasi (KIE) 
Tabel 5

Distribusi KIE pada responden di Wilayah Kerja UPTD Puskesmas DTP

Sukarame tahun 2013

\begin{tabular}{|l|c|c|}
\hline \multicolumn{1}{|c|}{ KIE } & f & \% \\
\hline Mendapat KIE & 182 & 45,5 \\
\hline Tidak mendapat KIE & 218 & 54,5 \\
\hline Jumlah & $\mathbf{4 0 0}$ & $\mathbf{1 0 0}$ \\
\hline
\end{tabular}

Data pada tabel 5 menunjukkan bahwa sebagian besar responden tidak mendapat KIE dari petugas kesehatan yaitu sebanyak $54.5 \%$, dan yang mendapat KIE sebanyak $45.5 \%$.

e. Dukungan dari suami

Tabel 6

Distribusi dukungan suami pada responden di Wilayah Kerja UPTD Puskesmas DTP Sukarame tahun 2013

\begin{tabular}{|l|c|c|}
\hline \multicolumn{1}{|c|}{ Dukungan suami } & f & \% \\
\hline Mendapat dukungan & 107 & 26,7 \\
\hline Tidak mendapat dukungan & 293 & 73,3 \\
\hline Jumlah & $\mathbf{4 0 0}$ & $\mathbf{1 0 0}$ \\
\hline
\end{tabular}

Data pada tabel 6 menunjukkan bahwa sebagian besar responden tidak mendapat dukungan suami yaitu sebesar $73.3 \%$, dan yang mendapat dukungan suami sebanyak $26.7 \%$.

f. Ekonomi

Tabel 7

Distribusi ekonomi responden di Wilayah Kerja UPTD Puskesmas DTP Sukarame tahun 2013

\begin{tabular}{|l|c|c|}
\hline \multicolumn{1}{|c|}{ Ekonomi } & f & \% \\
\hline Rendah $<$ UMR & 259 & 64,8 \\
\hline Tinggi $\geq$ UMR & 141 & 35,2 \\
\hline Jumlah & $\mathbf{4 0 0}$ & $\mathbf{1 0 0}$ \\
\hline
\end{tabular}

Data pada tabel 7 menunjukkan bahwa sebagian besar responden memiliki pendapatan kurang dari UMR yaitu sebesar $64.8 \%$, dan yang memiliki pendapat lebih dari UMR sebanyak 35.2\%.

\section{E. Pembahasan}

\section{Faktor Usia}

Umur merupakan salah satu faktor yang berperan dalam pemilihan kontrasepsi oleh wanita usia subur. Mengingat tujuan dari penggunaan kontrasepsi itu sendiri apakah untuk menunda kehamilan, menjarangkan kehamilan atau bahkan mengakhiri kesuburan. Berdasarkan dari hasil penelitian ini diketahui bahwa ibu wanita usia subur yang penulis teliti sebagian besar pada kelompok usia 2035 tahun yaitu $61 \%$, dan pada kelompok usia < 20 tahun sebanyak 29.3\%, sedangkan pada kelompok usia > 35 tahun sebanyak 9,8\%.

Melihat data-data tersebut, umur berperan dalam pola pelayanan kontrasepsi kepada masyarakat yang berkaitan dengan memperhatikan kurun reproduksi sehat, dimana pada wanita dengan umur 20-35 tahun merupakan fase menjarangkan kehamilan. 
Menurut Hartanto (2003) usia 20-30 tahun diperlukan kontrasepsi yang mempunyai efektifitas tinggi, eversibilitas cukup tinggi karena peserta masih mengharapkan punya anak lagi,dapat dipakai 2-4 tahun yaitu sesuai dengan anak yang direncanakan, tidak menghambat air susu ibu (ASI) karena ASI adalah makanan terbaik untuk bayi sampai umur 2 tahun dan akan mempengaruhi angka kesakitan dan kematian anak maka dari itu alat kontrasepsi suntik dapat di jadikan pilihan kedua setelah IUD.

Hal ini sesuai dengan Rizarina (2004) yang menjelaskan bahwa sesuai dengan tujuan keluarga berencana, maka penggunaan kontrasepsi AKDR dapat menjarangkan kehamilan. Sehingga penggunaan kontrasepsi dapat dipakai oleh wanita usia produktif.

Pada wanita berumur $<20$ tahun merupakan fase menunda atau mencegah kehamilan sehingga wanita tersebut dapat memilih alat kontrasepsi dengan reversebilitas tinggi, artinya kembalinya kesuburan dapat terjamin maka prioritas penggunaan alat kontasepsi bisa menggunakan pil oral, penggunaan kondom kurang menguntungkan karena pasangan muda masih tinggi frekuensi senggamanya sehingga akan mempunyai kegagalan tinggi.

Periode umur wanita di atas 30 tahun, terutama diatas 35 tahun sebaiknya mengakhiri kehamilan setelah mempunyai 2 orang anak. Sehingga pilihan utama alat kontrasepsinya adalah kontrasepsi jangka panjang ataupun kontrasepsi mantap misalnya vasektomi atau tubektomi karena kontrasepsi ini dapat dipakai untuk jangka panjang dan tidak menambah kelainan yang sudah ada. Pada masa usia tua kelainan seperti penyakit jantung, darah tinggi, keganasan dan metabolik biasanya meningkat, oleh karena itu sebaiknya tidak diberikan cara kontrasepsi yang menambah kelainan tersebut,

\section{Paritas}

Responden dengan paritas primipara yaitu $64.3 \%$, dan paritas multipara sebanyak $28.8 \%$, sedangkan paritas grandepara sebanyak 7.0\%.Data tersebut menunjukan bahwa paritas lebih banyak terjadi pada primipara dibandingkan dengan multipara maupun grandemultipara, artinya pemilihan kontrasepsi yang digunakan dapat dilakukan bagi ibu-ibu yang menyusui maupun digunakan oleh semua wanita usia subur.

Hal ini sejalan dengan yang dikemukakan Krisnadi (2007) bahwa KB suntik dapat digunakan wanita berbagai golongan umur, baik yang sudah maupun yang belum mempunyai anak. Dengan mempertimbangkan jumlah anak, maka pengguna KB diperlukan untuk menunda kehamilan, menjarangkan kehamilan atau mengakhiri fungsi reproduksi.

Sulastari (2005) pun menjelaskan bahwa umumnya setiap pasangan yang menggunakan kontrasepsi dilandasi keinginan yang jelas, apakah untuk menunda kelahiran anak pertama (postponing), menjarangkan anak (spacing), atau membatasi (limiting) jumlah anak yang diinginkan. Berdasarkan data di atas penulis dapat berasumsi bahwa paritas ini lebih banyak pada primipara disebabkan karena pada primipara lebih mempertimbangkan lagi untuk menambah jumlah anak atau untuk menjarangkan kehamilan dan menunda kehamilan. Jumlah anak (paritas) sangat mempengaruhi dalam pemilihan kontrasepsi apalagi pada primipara yang masih trauma dengan persalinan sebelumnya. Dari hasil penelitian, ibu usia subur lebih banyak menggunakan KB suntik dibandingkan dengan IUD, hal ini mengindikasikan kontrasepsi suntik dapat digunakan pada ibu yang memiliki anak maupun ibu yang belum mempunyai anak 


\section{Pendidikan}

Karkateristik demografi yang turut menjadi pertimbangan dalam pemilihan kontrasepsi adalah tingkat pendidikan. Penelitian menunjukkan bahwa tingkat pendidikan yang dimiliki mempunyai pengaruh yang kuat pada perilaku reproduksi dan penggunaan alat kontrasepsi. Dari hasil penelitian ini, tingkat pendidikan responden mayoritas dari pendidikan responden sebagian termasuk rendah yaitu sebanyak 53.3\%, dan pendidikan tinggi sebanyak $46.8 \%$.

Dimana pendidikan merupakan salah satu faktor penentu pada gaya hidup dan status kehidupan seseorang dalam masyarakat. Menurut Viviroy mengungkapkan bahwa pendidikan masyarakat merupakan indikator daya intelektual yang akan mempengaruhi pengetahuannya, artinya pengetahuan seseorang dapat dinilai dari tingkat pendidikannya karena semakin tinggi pendidikan ibu maka cara untuk mendapat informasi yang lebih banyak tentang alat kontrasepsi. Hasil ini sesuai dengan data SDKI 2010-2012 yang menunjukkan bahwa tingkat pendidikan ibu mempengaruhi pengetahuan ibu mengenai Alat Kontrasepsi Spiral.

Berdasarkan uraian tersebut, pendidikan berpengaruh terhadap perilaku dalam perawatan kesehatannya, seperti yang diungkapkan teori bahwa pendidikan wanita mempengaruhi banyak hal diantaranya perawatan anak, pendidikan, pengembangan fisik serta mental dan keberhasilan program KB. Tingkat pendidikan sangat berpengaruh terhadap pemahaman kontrasepsi, tetapi tidak dijadikan jaminan dengan pendidikan yang tinggi akan memahami pengetahuan kontrasepsi. Penyuluhan terhadap ibu usia subur sangat diperlukan untuk memberikan pengetahuan mengenai kesehatan pada anaknya, perubahan yang berkaitan dengan pertumbuhan dan perkembangan anak.

\section{Kurangnya KIE}

Rendahnya penggunaan kontrasepsi IUD juga berkaitan dengan masalah peran petugas sebagai pelaksana program Kesehatan Ibu dan Anak (KIA) di Posyandu dan di Puskesmas. Dari hasil penelitian yang dilakukan, peneliti menemukan sebagian besar responden tidak mendapat KIE dari petugas kesehatan yaitu sebanyak $54.5 \%$, dan yang mendapat KIE sebanyak $45.5 \%$. artinya mayoritas responden tidak mendapatkan konseling yang jelas serta transparan mengenai kontrasepsi IUD.

Kondisi tersebut menunjukkan bahwa pelayanan Komunikasi Informasi dan Edukasi belum menyentuh pada kognitif dan kesadaran masyarakat. Artinya kondisi dilapangan belum ada upaya dalam meningkatkan jaminan dan perlindungan pengguna kontrasepsi dengan prioritas pada penanggulangan efek samping dan komplikasi.

Hal ini ditunjukkan dengan masih banyaknya responden yang menganggap kurang adekuat terhadap KIE tersebut. Menurut Sarosa (2009) baik buruknya penerimaan masayrakat terhadap program keluarga berencana mencerminkan baik buruknya pelayanan KIE oleh tenaga kesehatanb, dimana hasil tersebut juga diketahui karena sangat dipengaruhi oleh berbagai program advokasi, dan konseling yang dilakukan Pemerintah dan partisipasi masyarakat. Partisipasi masyarakat terbesar dirasakan kontribusinya melalui pembinaan kesertaan ber $\mathrm{KB}$ di lini lapangan.

Oleh karena itu menurut BKKBN (2004) upaya pemerintah untuk meningkatkan dan mengatasi keluhan akseptor adalah dengan dengan menyelenggarakan promosi dan pemenuhan hak-hak dan kesehatan reproduksi termasuk advokasi, komunikasi, informasi, edukasi dan konseling bidang $\mathrm{KB}$, kelangsungan hidup ibu, bayi dan anak serta 
penanggulangan masalah-masalah kesehatan reproduksi.

Sasaran program ini antara lain meningkatnya persentase pasangan usia subur (PUS) yang ber-KB secara mandiri serta meningkatnya cakupan dan mutu pelayanan KB dan kesehatan reproduksi yang diselenggarakan oleh masyarakat dan jumlah lembaga yang secara mandiri menyelenggarakan pelayanan KB dan kesehatan reproduksi.

Hasil penelitian ini sesaui dengan Herlinawati (2008) penggunaan alat kontrasepsi oleh PUS (Pasangan Usia Subur) sangat penting tetapi banyak mengalami drop out. Drop out penggunaan alat kontrasepsi dipengaruhi oleh beberapa faktor selain faktor individu dan lingkungan adalah faktor program yaitu pelayanan KIE (Komunikasi,Informasi, edukasi) meliputi macam KIE KB dan macam konseling $\mathrm{KB}$ dan kualitas pelayanan kontrasepsi (meliputi pilihan metoda kontrasepsi, kemudahan pelayanan dan pemberian informasi).

\section{Dukungan Suami}

Dukungan suami terhadap pemilihan kontrasepsi merupakan faktor penting bagi ibu usia subur untuk menentukan penggunaan kontrasepsi. Dari hasil penelitian menunjukkan bahwa sebagian besar responden tidak mendapatkan dukungan dari suami untuk menggunakan kontrasepsi IUD yaitu sebesar $73.3 \%$, dan yang mendapat dukungan suami sebanyak $26.7 \%$. Rendahnya dukungan suami tersebut suami untuk memilih alat kontrasepsi bagi istrinya merupakan suatu respon dari pengetahuan dan sikap terhadap pemilihan alat dan obat kontrasepsi AKDR.

Peran suami dalam program KB dan Kesehatan Reproduksi yang berhubungan dengan kesehatan maternal adalah seperti menjadi akseptor $\mathrm{KB}$, mendukung istri menggunakan kontrasepsi, menrencanakan jumlah anak bersama pasangannya, membantu mempertahankan dan meningkatkan kesehatan ibu hamil, merencanakan persalinan yang aman oleh tenaga kesehatan; menghindari keterlambatan dalam mencari pertolongan medis; membantu perawatan ibu dan bayi setelah persalinan.

Suami juga sebaiknya ikut menemani istrinya menemui konselor $\mathrm{KB}$ atau petugas kesehatan, sehingga mereka bisa bersama-sama mengetahui metode KB yang tersedia dan memilih salah satu metode yang tepat, mengantisipasi jika terjadi efek samping dan bagaimana cara mengatasinya. Hasil penelitian secara random menemukan bahwa rendahnya minat responden dalam penggunaan kontrasepsi IUD menurun pada istri yang tidak mendapatkan dukungan dari suaminya.

Menurut Alfiyah (2006) kesehatan reproduksi merupakan keadaan kesejahteraan fisik, mental, dan sosial yang utuh dan bukan hanya tidak adanya penyakit atau kekurangan sesuatu yang berhubungan dengan sistem reproduksi, fungsi-fungsi, serta proses-prosesnya". Dan untuk mendukung kesehatan reproduksi istri, suami memiliki tiga peran sangat penting. Pertama, menggunakan atau mendukung pemakaian alat kontrasepsi yang dapat mengontrol waktu dan jumlah kehamilan. Kedua, berupaya agar perempuan mendapatkan dukungan emosional, pemenuhan gizi yang seimbang, dan pemenuhan fisik lainnya. Ketiga, mendukung perempuan selama masa kehamilan, persalinan, dan periode setelah persalinan.

Berdasarkan hasil penelitian ini, umumnya jawaban kuesioner adalah kurang mendapat dukungan suami atas pemilihan alat kontrasepsi AKDR dimana menurut ibu suami arang memberikan dukungan emosional bahkan cenderung melarangnya dengan alasan kurang nyaman saat berhubungan intim, suami juga tidak bersedia 
mengantar ibu memasang alat kontrasepsi AKDR.

Hal ini sesuai dengan teori yang dikemukakan oleh Notoatmodjo yaitu Dukungan suami mempunyai pengaruh lebih baik untuk menginformasikan arti penting menggunakan kontrasepsi. Dengan adanya dukungan suami sebagai stimulus terhadap Ibu-ibu yang ingin menggunakan kontrasepsi, maka masyarakat khususnya ibu yang ingin menggunakan kontrasepsi harus ada dukungan suaminya dan partisipasi suami tidak sekedar memberikan sumbangan tenaga, tetapi dalam segala sesuatu yang ada dalam dirinya,meliputi tenaga,uang, materi dan pikiran. Keempat komponen ini dapat dilibatkan dalam upaya meningkatkan kesehatan diri, keluarga ataupun lingkungan.

\section{Ekonomi}

Masalah ekonomi juga dapat menjadi bahan pertimbangan lain untuk menggunakan kontrasepsi IUD, dari hasil penelitian ditemukan bahwa sebagian besar responden memiliki pendapatan kurang dari UMR yaitu sebesar $64.8 \%$, dan yang memiliki pendapat lebih dari UMR sebanyak $35.2 \%$. Responden berpendapat harga pemasangan IUD dirasakan berat dan

\section{F. Simpulan dan saran}

Simpulan dari penelitian ini adalah :

1. Sebagian besar pada kelompok usia 20-35 tahun yaitu $61 \%$, dan pada kelompok usia < 20 tahun sebanyak $29.3 \%$, sedangkan pada kelompok usia > 35 tahun sebanyak 9,8\%.

2. Paritas responden sebagian besar termasuk primipara yaitu $64.3 \%$, dan paritas multipara sebanyak $28.8 \%$, sedangkan paritas grandepara sebanyak $7.0 \%$.

3. Pendidikan responden sebagian termasuk rendah yaitu sebanyak $53.3 \%$, dan pendidikan tinggi sebanyak $46.8 \%$. mahal. Sebagian besar responden memilih menggunakan uang tersebut untuk keperluan yang lebih pentingbagi keluarganya. Dari hasil penelitian diperoleh keterangan sumber pendapatan keluarga umumnya dari bidang wiraswasta dan dagang, dimana ibu bekerja ikut membantu dalam menambah pendapatan keluarga.

Hal ini sesuai dengan teori yang dikemukakan oleh prawiroharjo yaitu Faktor yang mempengaruhi pasangan usia subur memilih alat kontrasepsi AKDR salah satunya disebabkan ekonomi. Semua keluarga terutama ibuibu peserta KB yang mengalami kegagalan kontrasepsi ataupun akibat PHK atau belum bekerja.

Hal ini sesuai dengan menurut Rosadi (2008) dampak nyata yang muncul saat ini antara lain lemahnya kemandirian ber-KB dan tingginya "drop out" akseptor akibat tidak terjangkaunya alat kontrasepsi. Walaupun program pemerintah saat ini telah ada program untuk pemberian pelayanan kontrasepsi secara gratis, namun tetap saja masih banyak masyarakat yang masih belum memanfaatkannya.

4. Sebagian besar responden tidak mendapat KIE dari petugas kesehatan yaitu sebanyak $54.5 \%$, dan yang mendapat KIE sebanyak $45.5 \%$.

5. Sebagian besar responden tidak mendapat KIE dari petugas kesehatan yaitu sebanyak $54.5 \%$, dan yang mendapat KIE sebanyak $45.5 \%$.

6. Sebagian besar responden tidak mendapat dukungan suami yaitu sebesar $73.3 \%$, dan yang mendapat dukungan suami sebanyak $26.7 \%$.

7. Sebagian besar responden memiliki pendapatan kurang dari UMR yaitu sebesar $64.8 \%$, dan yang memiliki 
pendapat lebih dari UMR sebanyak $35.2 \%$.

Saran yang direkomendasikan bahwa penggunaan alat kontasepsi jangka panjang khususnya IUD petugas perlu melakukan sosialisasi sesuai dengan tujuan dan karakteristik akseptor. Disamping itu masyarakat perlu meningkatkan pengetahuan tentang alat kontrasepsi sesuai dengan peruntukannya.

\section{G. Referensi}

Bakrie,. Pertumbuhan

Penduduk Indonesia Menghawatirkan. 2008 (Diunduh tanggal 5 Maret 2011) Terdapat dari http://www.papuapos.com

$\mathrm{BKKBN}, . \mathrm{KB}$

Memberikan Keuntungan. 2005 (Diunduh tanggal 5 Maret 2011)Terdapat dari http://www.bkkbn.go.id BKKBN, Laju Pertumbuhan penduduk. 2008

Hartanto. Keluarga Berencana dan Kontrasepsi. Jakarta. Pustaka Sinar Harapan. 2002

Hidayat, Metode Penelitian Kebidanan Teknik Analisis Data. Salemba Medika. Jakarta. 2007

Kristiani, 2005. Pengaruh Program safe Motherhood pada Kinerja Bidan Desa. Dari http:/ww.ugm.ac.id diakses tahun 2010

Kodim, Nasirin.2007. Artikel, Jaringan Pelatihan Dalam Peningkatan Derajat Kesehatan from : http://www.tempo.co.id/medika/arsip

Kuntjoroningrat, Dasar Kesehatan masyarakat. 1999 Rineka cipta .

Laporan Pukesmas..Profil Kesehatan Puskesmas Sukarame tahun 2012.
Laporan Dinas Kesehatan Kabupaten Tasikmalaya tahun 2009.

Luminare,

Kesehatan

Reproduksi, Bukan Cuma Urusan Istri. 2008 (Diunduh tanggal 5 Maret 2011) Terdapat www.glorianet.org/keluarga/pria/

Maryani. Cara Tepat Memilih Alat Kontrasepsi Keluarga Berencana bagi Wanita. 2005. (Diunduh tanggal 5 Maret 2011) Terdapat dari http://www.tempo.co.id

Notoatmodjo.

Metodologi

Penelitian. Rhineka Cipta, 2005

Notoatmodjo.

Promosi kesehatan : teori dan aplikasi. 2005 Rhineka Cipta. Jakarta

Prawirohardjo,. Buku Acuan

Pelayanan Pelayanan Kebidanan. 2003..Yayasan Bina Pustaka Sarwono PrawirohardjoRahmat,. Pengetahuan dan Pengukurannya. 2005

Sarwono

Obstetric

Ginekologi, 2006 .Pustaka Indonesia . Jakarta

Sihombing, 2008. Jayawijaya Watch Project Health Section. From : http://www.depkes.go.id diakses tahun 2011

Subagyo,Alat KB Mana yang Cocok?(Diunduh tanggal 8 Maret 2011)2005 tersedia dari :http://bkkbn.go.id

Sulastari. Pilihan Yang Rasional. 2005 (Diunduh tanggal 12 Maret 2011) Terdapat dari Dari http://www.pokas.bkkbn.go.id

Vebrianto, Antropologi kesehatan. 2005 Graham Ilmu. Jakarta

Yahya and Ngalimun.2004 Profesionalisme Sistem Pelayanan Kesehatan Ibu Dan Anak (KIA) from http://www.path.org/files/ diakses tahun 2011 